\title{
ENSINO PRIMÁRIO TIPICAMENTE RURAL NO ESTADO DE SÃO PAULO: GRANJAS ESCOLARES, GRUPOS ESCOLARES RURAIS E ESCOLAS TÍPICAS RURAIS (1933 - 1968)
}

\section{Resenha do livro:}

MORAES, A. I. M. Ensino primário tipicamente rural no Estado de São Paulo: granjas escolares, grupos escolares rurais e escolas típicas rurais (1933 - 1968). São Paulo: Cultura Acadêmica, 2014.

\section{Autoria da resenha: Cláudio Rodrigues da Silva}

O livro Ensino primário tipicamente rural no Estado de São Paulo: granjas escolares, grupos escolares rurais e escolas típicas rurais (1933 - 1968), publicado pela Editora Cultura Acadêmica em 2014 e disponível para download gratuitamente na página dessa Editora ${ }^{1}$, é resultado de pesquisa histórica em nível de Mestrado em Educação, desenvolvida por Agnes Moraes, sob orientação da Profa. Dra. Rosa Fátima de Souza, que, no Prefácio (p. 15), recomenda a leitura desse livro, que "[...] muito contribui para a compreensão dos (des)caminhos da educação pública e das lutas sociais no país."

Esses três tipos de escolas rurais pesquisadas são, segundo Moraes, singulares, pois expressam o ideário dos ruralistas pedagógicos, que preconizavam uma educação específica para o campo.

Essas escolas eram diferenciadas, tanto no que se refere aos aspectos arquitetônicos, quanto no que tange aos programas de ensino. Para funcionarem em conformidade com o concebido, elas demandavam terrenos e arquiteturas específicas, bem como professores com formação especializada para atuação na educação primária rural. A autora defende que essas escolas foram concebidas em consonância com a proposta do ruralismo pedagógico.

A pesquisa teve como objetivo geral a reconstituição de aspetos da história dos três tipos de escolas mencionadas, com vistas a compreender características e especificidades dessas escolas, considerando-se as dimensões políticas, econômicas e culturais relacionadas com a criação delas.

A hipótese de Moraes é de que essas escolas foram concebidas visando atender demandas mais prementes daquele momento, entre elas a constituição de uma identidade nacional, o combate ao êxodo rural, a difusão do sanitarismo e a formação para o trabalho.

A relevância da pesquisa decorre de duas razões principais: a) a escassa produção acadêmico-científica sobre o tema; b) o fato de a autora abordar a educação escolar (a ser) propiciada aos povos trabalhadores do campo, uma questão polêmica e candente, tanto em tempos pretéritos quanto na atualidade.

Diversas foram as fontes utilizadas para a realização dessa pesquisa, em especial documentos oficiais dos governos federal e estadual paulista - Leis, Decretos, Relatórios dos Delegados Regionais de Ensino e Mensagens dos Governadores -, bem como periódicos especializados na temática pesquisada e textos de ruralistas pedagógicos.

Esse livro, em termos estruturais, totaliza 215 páginas; além da parte nuclear, contém dois Anexos. Apresenta, ainda, imagens relacionadas aos três tipos de escolas mencionadas e à educação rural no período delimitado.

O Anexo A, Fontes para o estudo de escolas de ensino típico rural no Estado de São Paulo (1933 - 1970), apresenta fontes documentais acerca das escolas de ensino primário 
tipicamente rural nesse Estado. O Anexo B, Mapeamento de escolas de ensino típico rural no Estado de São Paulo (1933 - 1968), apresenta principalmente a denominação e a distribuição dessas escolas por diferentes municípios desse Estado. Esses Anexos propiciam subsídios para pesquisas correlatas.

No primeiro capítulo, Normatização para o ensino primário rural em âmbito federal ou estadual (1933-1968), Moraes apresenta apontamentos acerca da conjuntura e da legislação que precederam ou resultaram na criação, na conversão e na instalação das escolas mencionadas.

No segundo capítulo, Propostas educativas de ensino típico rural no Estado de São Paulo, a autora apresenta os quesitos legais que regulamentaram o funcionamento dessas escolas, problematiza as concepções pedagógicas subjacentes a elas, discute os principais aspectos da concepção de educação do ruralismo pedagógico e aponta relações de proximidade entre essas escolas e o ideário ruralista de educação.

No terceiro capítulo, Granjas escolares, grupos escolares rurais e escolas típicas rurais: localização e distribuição pelo estado de São Paulo, Moraes apresenta um mapeamento dessas escolas, em termos de localização, assim como reflexões acerca de implicações da distribuição dessas escolas pelo território paulista.

No quarto capítulo, Vestígios da cultura escolar no ensino típico rural, a autora apresenta vestígios de funcionamento, de práticas e da cultura escolar de algumas dessas escolas, com ênfase em aspectos concernentes à arquitetura e à organização administrativopedagógica.

Entre os pontos levantados na conclusão, a autora aponta que, mais especificamente no que se refere às granjas escolares foram encontrados indícios de experiências análogas no México, aventando a hipótese - a ser investigada - de que a gênese desse tipo de escola estaria nos Estados Unidos da América, o que é um indicativo da circulação de modelos pedagógicos na história da educação primária rural brasileira.

Moraes destaca a relação necessária entre sociedade e educação. Como destacado, à educação escolar, naquele momento histórico, foram atribuídas incumbências relacionadas à formação de uma identidade nacional, à formação para o trabalho em conformidade com o projeto político-econômico hegemônico à época, ao combate ao êxodo rural, ao sanitarismo - tanto no sentido material quanto no sentido ideológico -, entre outras questões prementes e indispensáveis para se evitar ou atenuar tensões ou conflitos sociais.

Essas escolas, segundo a autora, foram criadas e mantidas num momento em que estava em voga o ideário de um Brasil de vocação agrária e foram extintas conforme esse ideário entra em declínio e o industrialismo ascende. Assim, o ruralismo pedagógico também declina, passando a prevalecer o ideário de uma escola comum para o campo e para a cidade. A autora aventa que essas escolas foram extintas em fins da década de 1960, com a Reforma de 1968, que consolidou o ensino comum.

Para Moraes as escolas mencionadas representaram um percentual restrito, se comparado ao total de escolas primárias rurais no Estado de São Paulo. Caso funcionassem em conformidade com o concebido, essas escolas, como já ressaltado, se comparadas à ampla maioria das escolas primárias rurais, representariam avanços, em termos pedagógicos, em especial no que se refere à arquitetura e à formação de professores, porém, seriam mais onerosas, em termos financeiros.

Essas escolas, porém, não ficaram imunes à precariedade que marca, até os dias atuais, a educação escolar propiciada pelo Estado aos povos trabalhadores do campo, já que, além de uma educação reduzida, em termos de tempo de estudo e de componentes curriculares, as políticas educacionais para o campo foram historicamente marcadas pela morosidade, incipiência, insuficiência, inconstância e precariedade, especialmente em 
decorrência da relação custo-benefício, critério determinante na concepção e na execução das políticas educacionais para o campo especialmente.

A autora ressalta, ainda, que os povos trabalhadores do campo tiveram diversos direitos negados ou restringidos, como, por exemplo, o direito à educação escolar, que, naquele momento histórico, tinha implicações com o direito ao voto, negado às pessoas analfabetas.

Além de apresentar dados referentes a esses três tipos de escolas tipicamente rurais, até então não pesquisadas, o livro propicia importante contribuição para o preenchimento de lacunas na área da História da educação rural, bem como para reflexões acerca de questões candentes na atualidade, marcada pela intensificação de políticas de capitalismo neoliberal, que têm como um de seus principais desdobramentos a ênfase na relação custobenefício, resultando na adoção de medidas nocivas à educação pública.

Exemplificam isso o processo de fechamento de milhares de escolas no campo em diferentes pontos do território brasileiro, e, mais especificamente no caso do Estado de São Paulo, a denominada reorganização de escolas da rede pública estadual paulista, que também implica fechamento de escolas. Verifica-se, assim, que a relação custo-benefício é, com as devidas ressalvas em termos de espaço e tempo, uma espécie de permanência histórica nas políticas educacionais brasileiras e faz parte das táticas do Estado para se isentar da responsabilidade financeira pela manutenção da educação e das escolas públicas.

Ao problematizar as concepções de educação dos ruralistas pedagógicos, defensores de uma educação exclusiva e diferenciada para o campo, e dos escolanovistas, defensores de uma educação comum para a cidade e para o campo, Moraes propicia dados que ajudam a refletir sobre outro ponto também premente na atualidade, qual seja, a questão da educação para, no ou do campo, um debate que não se restringe à escolha de uma ou outra preposição, que têm significativas diferenças teórico-práticas entre si, inclusive no que tange a concepções de educação, de campo e de mundo ${ }^{2}$.

Como destaca, no Prefácio (p. 16), Rosa Fátima de Souza,

[...] o livro convida à reflexão, atitude extremamente necessária em uma atualidade na qual enfrentamos não somente o solapamento da memória coletiva, mas o risco de retrocesso das conquistas sociais e do fortalecimento da democracia alcançados pela sociedade brasileira nas últimas décadas.

Portanto, além de permitir o entendimento de aspectos históricos da educação, o livro propicia dados que ajudam a problematizar e a entender, fazendo uso de palavras de Moraes (p. 40), o "vai e vem [e o] vem e vai" das políticas educacionais.

\footnotetext{
${ }^{1} \mathrm{http}: / /$ www.culturaacademica.com.br/catalogo-detalhe.asp?ctl_id=479

${ }^{2}$ Essa polêmica permeou debates do III Seminário Nacional de Estudos e Pesquisas sobre Educação no Campo, V Jornada de Educação Especial no Campo e XIII Jornada do HISTEDBR, realizado na Universidade Federal de São Carlos em outubro de 2015.
} 